\title{
"New Music" and the "New Negro": The Background of William Grant Still's "Afro- American Symphony"
}

\section{Citation}

Oja, Carol J. 1992. "New Music" and the "New Negro": The Background of William Grant Still's "Afro-American Symphony". Black Music Research Journal 12(2): 145-169.

\section{Published Version}

http://www.jstor.org/pss/779440

\section{Permanent link}

http://nrs.harvard.edu/urn-3:HUL.InstRepos:2643639

\section{Terms of Use}

This article was downloaded from Harvard University's DASH repository, and is made available under the terms and conditions applicable to Other Posted Material, as set forth at http:// nrs.harvard.edu/urn-3:HUL.InstRepos:dash.current.terms-of-use\#LAA

\section{Share Your Story}

The Harvard community has made this article openly available. Please share how this access benefits you. Submit a story.

Accessibility 


\title{
"New Music" and the "New Negro": The Background of William Grant Still's "Afro-American Symphony"
}

\author{
Carol J. Oja \\ Black Music Research Journal, Vol. 12, No. 2. (Autumn, 1992), pp. 145-169.
}

Stable URL:

http://links.jstor.org/sici?sici=0276-3605\%28199223\%2912\%3A2\%3C145\%3A\%22MAT\%22N\%3E2.0.CO\%3B2-2

Black Music Research Journal is currently published by Center for Black Music Research - Columbia College Chicago.

Your use of the JSTOR archive indicates your acceptance of JSTOR's Terms and Conditions of Use, available at http://www.jstor.org/about/terms.html. JSTOR's Terms and Conditions of Use provides, in part, that unless you have obtained prior permission, you may not download an entire issue of a journal or multiple copies of articles, and you may use content in the JSTOR archive only for your personal, non-commercial use.

Please contact the publisher regarding any further use of this work. Publisher contact information may be obtained at http://www.jstor.org/journals/cbmr.html.

Each copy of any part of a JSTOR transmission must contain the same copyright notice that appears on the screen or printed page of such transmission.

JSTOR is an independent not-for-profit organization dedicated to and preserving a digital archive of scholarly journals. For more information regarding JSTOR, please contact support@jstor.org. 


\title{
"NEW MUSIC" AND THE "NEW NEGRO": THE BACKGROUND OF WILLIAM GRANT STILL'S AFRO-AMERICAN SYMPHONY
}

\author{
CAROL J. OJA
}

William Grant Still's Afro-American Symphony has taken on mythic proportions in the history of African-American music. First performed in 1931, it stands as a powerful symbol of black achievement-as one of the first symphonies by an African-American composer, as the first work by a black to be performed by a major orchestra, and as one of the most widely recognized musical manifestations of the Harlem Renaissance. Yet, in addition to being regarded solely for its position within black American culture - a point of view taken by most writers about the work, from Eileen Southern in The Music of Black Americans to Rae Linda Brown and others in specific studies of the piece (Southern 1983, 424-425; Brown 1990, 75) - the symphony also deserves consideration in terms of the broad artistic movements of the day. Alongside its preeminent position among black concert works of the early twentieth century, the Afro-American Symphony belongs with a group of pivotal pieces by white composers written in 1930 and 1931, especially Aaron Copland's Piano Variations, Ruth Crawford's String Quartet, and Edgard Varèse's Ionisation. These compositions signal a time of profound transition in American culture, capping a decade of economic prosperity and exceptional artistic openness when the values and styles of the past faced bold challenges. Change marched under many banners during the twenties, whether as the New Woman, the New Negro, the New Art, or the New Music-making the "new," as used in the lingo of the day, synonymous with all sorts of freedoms. At the same time, these works

\footnotetext{
CAROL J. OJA is Interim Director of the Institute for Studies in American Music and Associate Professor at Brooklyn College and the Graduate School of the City University of New York. She is the author of Colin McPhee: Composer in Two Worlds (Smithsonian Institution Press, 1990) and editor of American Music Recordings: A Discography of Twentieth-Century U.S. Composers (Institute for Studies in American Music, 1982). This article is drawn from her forthcoming book, The Rise of Modernist Music in New York: Perspectives on the 1920s (Oxford University Press).
} 
also stood on the brink of the Great Depression, when economic instability caused many creative advances of the previous decade to be eclipsed by a more accessible musical language.

Still's Afro-American Symphony has been seen as part of a separate story from these other landmark works of the early 1930s. Yet it, like them, was a product of the vigorous young composers' movement of the previous decade, a movement that brought figures such as Copland, Henry Cowell, and Virgil Thomson their first public recognition. Still rose to prominence alongside them. Yet like most artistic figures in Harlem, he was forced to straddle two distinct yet intersecting worlds, one black and the other white. ${ }^{1}$ Within the span of only a few years he played in the orchestra of the historic Eubie Blake and Noble Sissle musical Shuffle Along, worked for the Pace and Handy Music Company and later for the Black Swan phonograph company, produced arrangements for black revues, and made his concert music a medium for expressing race pride. ${ }^{2}$ At mid-decade, however, he also simultaneously became part of the white young-modernist scene, studying with Varèse and having a substantial series of works performed in the major new music venues of the day. When the premiere of the Afro-American Symphony occurred, it did not take place in Harlem, but on one of these new music series-specifically, the American Composers' Concerts conducted by Howard Hanson at the Eastman School of Music-and the work was dedicated to Irving Schwerké, a music critic for the Paris edition of the Chicago Tribune. ${ }^{3}$ Hanson and Schwerké were part of an important chain

1. The historian Nathan Huggins has identified interchanges between blacks and whites as one of the most crucial factors in the Harlem Renaissance. For example, he writes of Claude McKay, a well-known literary figure in the New Negro movement: "While much of his writing was intensely expressive of Harlem, he nevertheless managed to remain outside and independent of it. White intellectuals were his main support and his primary intellectual association" (Huggins 1971, 25).

2. Still worked for Pace and Handy as "head" of the arranging staff; when the firm dissolved in 1921 and Pace launched the Black Swan record label, Still "continued as arranger ... and later superseded [Fletcher] Henderson as musical director" (Allen 1973, 10). Still's activities as an arranger remain obscure and deserve detailed investigation. According to Haas $(1975,6)$, "at various times he worked for Earl Carroll, Artie Shaw, Sophie Tucker, Don Voorhees, and Paul Whiteman," as well as for the CBS and Mutual broadcasting networks and for Willard Robison's "Deep River Hour" on NBC.

3. Still's relationship to Schwerké is an important subplot in the tale behind the AfroAmerican Symphony. Schwerke staunchly supported the young composer and received several revealing letters from him, which are now housed with the critic's papers at the Library of Congress. In one of them Still confided about the economic crisis that he faced around the time that the symphony was written: "It is unfortunate for a man of color who is ambitious to live in America. True (and I gladly admit it) there are many splendid 
of white supporters who helped spur Still's career. At some point in the mid-twenties Still must have recognized that to gain visibility as a concert composer in America he had to utilize the existing performance outlets, the most prominent of which were white. As the historian Henry May $(1959,86)$ has observed, "Negroes ... had to break into the dominant .. . culture of the day before they could break out of it."

Nonetheless, the relationship of the Afro-American Symphony to the modernist movement is fraught with powerful tensions. While Still's tie to the modernists, in terms of contact with colleagues and performance opportunities, remained strong throughout the twenties and made the premiere of the symphony possible, his ideological link became increasingly more tenuous as his style grew more conservative. In the years before the Afro-American Symphony, then, Still led a dual existence, part of which involved treading the same path as young white concert composers of his day and part of which kept him in step with his own people. At the same time as he lived in Harlem, his concert music was being performed downtown in the most important new music showcases of the day.

William Grant Still, together with a host of American creative artists, launched his career during an extraordinary decade. Fueled by strong national self-confidence following World War I, a new generation of composers, writers, and artists came upon the scene in the 1920s determined to establish themselves and their work. Included were the writers Ernest Hemingway and Langston Hughes, the composers Aaron Copland, Henry Cowell, and Edward Kennedy "Duke" Ellington, and the jazzmen Fletcher Henderson and James P. Johnson, most of whom pursued their careers in two principal locations, New York City and Paris. For those in New York, Green wich Village and Harlem were the main areas in which to live and work-areas separated physically by race yet linked psychologically by a shared sense of possibility. Although segregation held firm, it came under increasing challenge, making inter-

people here; broad minded; unselfish; judging a man from the standpoint of his worth rather than his color. Such men as Dr. Howard Hanson, Frank Patterson and many others. Such a man as my friend Varese proved to be when he was here. But there is a preponderance of those who are exactly the opposite. . . I have never felt this so keenly as in the past few months. Friends who would lend me a helping hand, who would make it possible for me to make a living for my family are unable to do anything because of those who are opposed to placing a colored man in any position of prominence. That is stating it mildly. . . . Unless there is a change soon I will be forced to abandon my aspirations and look to other means of gaining a livelihood or to go where such conditions do not exist" (Still 1931a). 
changes between blacks and whites more frequent. Whatever their race, these artists were conscious of living in a special time. In 1930 James Weldon Johnson could write, "The most outstanding phase of the development of the Negro in the United States during the past decade has been the recent literary and artistic emergence of the individual creative artist. . . . It seems rather like a sudden awakening, like an instantaneous change" (Johnson 1930, 260). And a few years later the white poet and literary critic Malcolm Cowley expressed a similar sense of wonder, recalling how his contemporaries during the twenties felt themselves to be "representatives of a new age" with "a sense of being somehow unique" (Cowley [1934] 1951, 8).

Composers of concert music shared this energy and optimism. Facing a music establishment solidly rooted in the performance of European masterworks, they banded together to found performing societies, magazines, and publishing firms to promote their work. Most prominent among these efforts were the International Composers' Guild, established by Varèse and Carlos Salzedo in 1921, and the League of Composers, founded two years later by Claire Reis and a group of defectors from the Guild (see Lott 1983; Reis [1955] 1974). Late in the decade, another wave of new music ventures appeared. In 1928, a year after the demise of the Guild, Varèse and his colleagues regrouped to form the Pan American Association, which focused on composers of the Americas rather than those of European fame (Root 1972). The Copland-Sessions Concerts began that same year as a kind of young peoples' annex of the League (Oja 1979). Concurrently, various publishing enterprises began to emerge, especially Modern Music, a "little magazine" founded in 1924 as an organ of the League of Composers, and Cos Cob Press, begun in 1929 to issue scores by young modernists (see Lederman 1983; Oja 1988). All of this activity took place in and around New York City. Meanwhile, in other parts of the country, composers were making similar efforts: Cowell started the New Music Society in California in 1925, first as a concert series and soon after as a publisher of scores and recordings; E. Robert Schmitz began the Pro-Musica Society in New York, eventually establishing chapters from coast to coast; and Howard Hanson, in Rochester, New York, founded the American Composers' Concerts, which lasted nearly half a century (see Mead 1981; Wiecki 1992; and Watanabe 1972).

William Grant Still played a role in many of these new music enterprises. He was the only black concert composer of his day to find a position in this otherwise all-white world. While Still by no means held 
the power or prominence of the modernist movement's leaders - at first Varèse, later Copland and Cowell-he joined a group of promising newcomers to New York, and his music appeared on programs of the International Composers' Guild and the American Composers' Concerts (see the Appendix for a detailed list of performances of his works). He was also a founding member of the Pan American Association and had works performed by George Barrère's Little Symphony Orchestra, an ensemble that regularly included new music on its concerts. These activities took place in the 1920s - that is, before the composition of the Afro-American Symphony - and in the next decade, Still received a commission from the League of Composers and had a work published in Cowell's New Music Orchestra Series. Thus, Still took part in the most important new music activities of the day, while at the same time he worked as an arranger for jazz bands and black theatrical productions. His degree of involvement in each modernist organization differed, and his position as the only black composer made race a persistent issue, especially in the expectations it raised for the kind of music he should be writing.

Still made his debut with the modernists at a concert of the International Composers' Guild on February 8, 1925, when his From the Land of Dreams, composed the previous year, received its premiere. This was his first piece to be presented by Varèse, who was to become one of his principal mentors. Two subsequent Guild programs included Still's music: a concert on January 24, 1926, with Levee Land and another on November 28, 1926, with Darker America. ${ }^{4}$ By the end of this association, Still had had more works performed by the Guild than most other Americans. This put him in an exceptional position, for Varèse's programming largely focused on new European works, most of which were being heard in the United States for the first time. Only Carl Ruggles, Carlos Salzedo, and Varèse himself-the latter two, of course, being

4. A list of the other works on these programs gives a sense of the company Still was keeping: (1) February 8, 1925, Aeolian Hall: Acario Cotapos, Three Preludes; Béla Bartók, Sonatina for Piano; Massimo Zanotti-Bianco, Materia; Henry Cowell, Ensemble; Carlos Salzedo, Trois poèmes de Stéphane Mallarmé; Anton Webern, Five Movements for String Quartet; Carlos Chàvez, Tres exàgonos. (2) January 24, 1926, Aeolian Hall: Eugene Goossens, Pastoral and Harlequinade; Carl Ruggles, Portals; Ottorino Respighi, Deità siloane; Marguerite Béclard d'Harcourt, Four Indian Folksongs; Vittorio Rieti, Sonata for Flute, Oboe, Bassoon, and Piano. (3) November 28, 1926, Aeolian Hall: Colin McPhee, Pastorale and Rondino; Ildebrando Pizzetti, Trio in A for Piano and Strings; Eugene Goossens, Three Pagan Hymns; Anton Webern, Fünf geistliche Lieder; Carlos Chàvez, Caballos de vapor (H.P.). 
European immigrants as well as codirectors of the Guild-received more hearings. Other Americans or American nationals, such as Cowell, Louis Gruenberg, Leo Ornstein, Dane Rudhyar, and Emerson Whithorne, were represented by one or at most two works. Thus, Still's substantial support by the Guild suggests he was highly regarded, perhaps even favored, by Varèse and other Guild leaders.

Still's first Guild performance seems to have grown directly out of his study with Varèse, which lasted from 1923 to 1925 (Southern 1983, 424). This was a decisive alliance, marking the onset of Still's activity as a composer of concert music and forging the connections that would make performances of his music possible. ${ }^{5}$ According to Still's wife, Verna Arvey, his introduction to Varèse came about through a series of serendipitous connections, and the story of how it happened has taken on the character of a legend. On a transatlantic trip in the early twenties, Varèse met Colonel Charles Young, described by Arvey as "a distinguished Negro who had seen thirty-four years of active service in the United States Army" (Arvey 1984, 64-65). Young impressed the composer so much that Varèse decided to offer a scholarship for a black to study with him. Varèse wrote to various prominent black musicians in New York, seeking a candidate. One letter reached the Black Swan phonograph company, where Still was working at the time, and Still contacted Varèse immediately. Varèse seems to have taken on few other pupils during this period, except for the Canadian-American composer Colin McPhee.

Encountering Varèse, arguably the most influential modernist composer in New York during the early twenties, opened up a new world for Still. Arvey credits the older man with making crucial connections for her husband, not only by presenting him in Guild concerts but by introducing him to major conductors of the day, including Leopold Stokowski, conductor of the Philadelphia Orchestra; Eugene Goossens, conductor of the Rochester Philharmonic Orchestra; and Georges Barrère, Varèse's fellow immigrant from France who was a well-known flutist and, as mentioned previously, conductor of the Little Symphony Orchestra. She also reports that Varèse, together with Frank Patterson, editor of the Musical Courier, introduced Still to Howard Hanson, who

5. At least one member of the Guild-Carl Ruggles - felt that Varèse unduly favored his students, as Ruggles complained in a letter to his friend and supporter Blanche Walton: "I've resigned from the Guild. ... I'm afraid it's degenerated into nothing but an advertising medium for Varèse and his pupils. Still etc" (Ruggles 1926). 
conducted the premiere of the Afro-American Symphony in 1931 (Arvey 1984, 65).

Study with Varèse helped Still get his music performed, and, according to Still, it also affected his compositional style. It appears that Still had composed only a few concert works before encountering Varèse. Arvey claims that as early as 1916 Still determined to "elevate the blues ... [to] a dignified position in symphonic literature" but that "most of these early efforts were lost before they were performed publicly" (Arvey 1975, 89-90). Once Still made contact with Varèse, however, his course changed. Yet, like many students of teachers with strong artistic personalities, Still faced a conflict in finding his own voice. Initially he modeled his music according to his teacher's ideals, but increasingly he faced those ideals with ambivalence. He later wrote:

[Varèse] took for himself, and encouraged in others, absolute freedom in composing. Inevitably, while I was studying with him, I began to think as he did and to compose music which was performed; music which was applauded by the avant-garde, such as were found in the International Composers' Guild. As a matter of fact, I was so intrigued by what I learned from Mr. Varese that I let it get the better of me. I became its servant, not its master. . . But at the same time, the things I learned from Mr. Vareselet us call them the horizons he opened up to me-have had a profound effect on the music I have written since (Still 1975b, 115).

The specific ways in which Still's early music was "ultramodern," as he and his wife later identified it, remain mysterious (Still 1975b, 115; Arvey 1984, 67). His principal work from this period, From the Land of Dreams, which marked Still's first appearance on a Guild concert, is now lost. It was scored for a chamber ensemble of flute, oboe, clarinet, bassoon, horn, viola, cello, double bass, bells, triangle, and three sopranos "used instrumentally" ([Varèse] 1925). According to Still, the work had an extramusical agenda, as frequently became true of his later compositions:

In the first two movements I have sought to depict, or rather to suggest, the flimsiness of dreams which fade before they have taken definite form. The varying moods of these movements may be construed as suggestions of the ever changing scenes which dreams unfold to the dreamer's vision. Some may contend that the last movement is too vigorous to be a part of the composition, but there are vivid dreams with clearly defined outlines. From these we often awake abruptly dwelling, as it were, on the borders of both the realm of fancy and of reality (quoted in [Varèse] 1925). 
Reviews of the concert on February 8, 1925, provide few clues to the work's style, but they do tell something about Still's standing in New York's new music community and about expectations for a black composer. The most revealing critiques came from Paul Rosenfeld and Olin Downes, the former a well-known champion of American creative artists in his regular column on new music for The Dial and the latter the chief music critic for the New York Times. Rosenfeld $(1925,352)$ identified Still as a figure worth watching, as a member of "the growing company of American musical embryonics," yet he pinpointed the same problem of teacher-student influence that Still himself articulated later: "Still has learned much from Edgar Varèse, his instructor, although he has not yet quite learned to speak out freely: a certain absence of freedom in the use of his ideas limits one's enjoyment, and the material of the first two sections of his composition is insufficiently contrasted." But Rosenfeld admired Still's orchestration and suggested that, despite its title and descriptive program, the piece included some African-American elements:

Mr. Still has a very sensuous approach to music. His employment of his instruments is at once rich and nude and decided. The upper ranges of his high soprano have an original penetrating colour. And the use of jazz motives in the last section of his work is more genuinely musical than any to which they have been put, by Milhaud, Gershwin, or any one else (Rosenfeld 1925, 352).

Rosenfeld included Still alongside white composers of his generation, yet he also introduced the black man as not just another young modernist but as something of a curiosity. He opened his review with the observation that "the promise of a new musical geography hovered in the air" at the Guild concert and proceeded to group Still with other "exotic" figures on the program, including Acario Cotapos from Chile, Massimo Zanotti-Bianco from Crete, and Carlos Chàvez from Mexico. Still's name stood alongside theirs as "a negro from Mississippi" (Rosenfeld 1925, 351). By contrast, Cowell did not receive similar treatment, in spite of the ethnographic flavor of his Ensemble for string quartet and Amerindian thundersticks that appeared on the program, nor did Béla Bartók or Anton Webern, two non-Americans who also had pieces performed that evening. Rosenfeld's grouping suggests that in this company he perceived a black American as an outsider. ${ }^{6}$

6. Other accounts of the period confirm Still's status as an exotic in the new music community. Witness Louise Varèse's recollection of a party hosted by Still after the premiere of From the Land of Dreams: "Still gave a dinner at his house in Harlem (wonderful 
While Rosenfeld dealt separately with race and style in evaluating Still's piece, Downes combined the two, touching on an issue that was to be central to Still's career. For Downes, most music on the program was "very bad and ineffectual" $\longrightarrow$ a judgment that all the young modernists faced repeatedly in newspaper reviews - yet he seemed especially disappointed in Still, saying he had "hoped for better things" from him. Downes expected Still, as an African-American composer, to write music indicative of his color. At the same time Downes showed surprising familiarity with Still's work in black musical theater:

[Still] knows the rollicking and often original and entertaining music performed at negro revues. But Mr. Varese, Mr. Still's teacher, has driven all that out of him. Is Mr. Still unaware that the cheapest melody in the revues he has orchestrated has more originality and inspiration in it than the curious noises he has manufactured? . . This is music unprofitable to compose or listen to (Downes 1925).

From the Land of Dreams was to remain Still's only work performed within the new music community that did not overtly address the theme of race. From the mid-twenties on, Still self-consciously embraced the very difference that separated him from his white colleagues, and Downes's words suggest the kind of pressures that shaped the young composer's decision to do so-pressures both direct and indirect, originating with both blacks and whites. Living in Harlem during the 1920s, Still was surrounded by creative artists, such as Langston Hughes and Claude McKay, who proudly celebrated their African-American heritage. ${ }^{7}$ These figures, whether overtly or not, provided an inspiration and model for a black form of creative expression. At the same time, many whites had a deep fascination with black culture, encouraging its exploration, and a number of white artists, from Copland to George Gershwin to Carl Van Vechten, incorporated black themes and idioms in their work.

fried chicken) in honor of Varèse and afterward a very large and formal reception with all the women in elaborate evening gowns. It was a very dignified and even solemn occasion. Varese and I stood together and were introduced individually in an exactly repeated formula to each one of the fifty or more guests. Still, as well as many of his dark guests, had ceremonious and even courtly manners that would have graced any embassy or king's court-the genetic memory of ancestral pride and ritualistic formality" (Varèse 1972, 227).

7. My focus here is largely on Still's position among the modernists of the twenties. Yet his contact with the main figures and ideology of the Harlem Renaissance deserves detailed documentary inquiry. Rae Linda Brown $(1990,75)$ suggests that the influence of the Harlem Renaissance on Still was "subtle" and that he was "not a conscious participant in the Negro Renaissance, [yet] his music speaks of the essence of the New Negro." 
For black artists this strong interest in Negro culture resulted in a tension between devising work that was identifiably African-American and following their own artistic vision. Sometimes the two coexisted comfortably, sometimes they did not. Many black writers, according to James Weldon Johnson (1930, 267) "made a natural attempt to get from under the weight that 'race' put upon their art." Still faced this same dilemma. At some point in the mid-twenties, he turned decisively to composing music representative of black culture, and for a time this remained his central theme, with the Afro-American Symphony being the most famous result. Yet his path from being an "ultramodern" composer to a "racial" one was by no means linear, as he later described:

After this period [of writing "ultramodern" music], I felt that I wanted for a while to devote myself to writing racial music. And here, because of my own racial background, a great many people decided that I ought to confine myself to that sort of music. In that too, I disagreed. I was glad to write Negro music then, and I still do it when I feel so inclined, for I have a great love and respect for the idiom. But it has certainly not been the only musical idiom to attract me (Still 1975b, 115). ${ }^{8}$

The conflict between a more dissonant-or "ultramodern"-musical style and an identifiably black one became central to Still's music in the years ahead. If his works leaned too far in the first direction, he faced the same kinds of criticisms hurled at all the young American modernists, whether for concocting "curious noises," as Downes wrote of From the Land of Dreams (Downes 1925), or for being "too sophisticated," as the black critic Alain Locke once stated (Locke 1936, 115). On the other hand, if Still incorporated all aspects of a given African-American idiom-melodic, formal, and especially harmonic-he risked having his music viewed as "simple" or "filled with naïveté," as was the case with a review of the Afro-American Symphony published in Modern Music (Balaban 1932, 183). Still, however, did not suddenly switch from one extreme to the other. Between the mid-twenties and the Afro-American Symphony he experimented with various solutions, most of which show him achieving an imaginative, if sometimes tentative, compromise. Fus-

8. One example of the pressure put upon black composers to write music that was clearly African-American appears in an announcement for a prize offered black composers by Captain John Wanamaker, Jr., of department store fame, which stated that "the use of the Negro idiom is preferred, [yet] other styles may be employed" ("Contest for Composers" 1930). 
ing the modernistic with the racial, his pieces continued to be promoted by new music organizations. ${ }^{9}$

Still's next performance by the International Composers' Guild came in January 1926 with the premiere of Levee Land, written for the celebrated black singer Florence Mills. It was a sensational way of proclaiming his new direction, and it drew a glittering crowd that included Gershwin, Van Vechten, and Arturo Toscanini. The event followed Gershwin's premiere two years earlier of Rhapsody in Blue with Paul Whiteman's Orchestra and also Eva Gauthier's performance in 1923 of popular songs by Gershwin (both in Aeolian Hall where the Guild concert also took place). With Still's Levee Land there was an added dimension, however. Not only did it bring the world of popular music into the hallowed sanctuary of the concert hall, but it involved a black singer associated with theatrical revues and cabarets. In reviewing the concert, Downes (1926a) disdained his white contemporaries for their unabashed fascination with Mills: "For the audience, it appeared that curiosity centered on the performance of Miss Mills-so much for our modern intellectuals of music!" But Rosenfeld $(1926,352)$ seems to have gotten caught up in the audience's enchantment, writing that there had "never [been] another voice with the infinitely relaxed, impersonal, bird-like quality of [Mills]."

Levee Land presaged the Afro-American Symphony in a number of ways. Just as Still sought in the symphony "to elevate a musical idiom typical of the American Negro to symphonic level" ("Notes on: The Afro-American Symphony" [n.d.]), so Levee Land brought a story about blacks in the Old South to the modern concert stage. As Still (1931c) wrote of the symphony: "[It] is not a tone picture of the 'New Negro.' It portrays that class of American Negroes who still cling to the old standards and traditions; those sons of the soil who differ but little, if at all, from their

9. The chronology of Still's turn to African-American themes deserves close scrutiny. According to the program note for From the Land of Dreams, he was becoming involved with racial themes even before his first performance by the Guild. Haas $(1975,145)$ confirms this by dating Darker America and From the Land of Dreams as 1924. The Guild notes also mention Three Fantastic Dances for chamber orchestra (a work that Arvey [1984, 66] claims was "never finished"), From the Black Belt for full orchestra (a work that was to be performed by Georges Barrère's Little Symphony Orchestra in 1926 and is dated by Haas as 1926), and Songs for Voice and Piano, composed for Madame Marya Freund, the Polish-French soprano who had given the French premiere of Schoenberg's Pierrot lunaire (the fate of these songs is unclear). The program goes on to say that Still "is now writing a choral work for mixed voices a cappella on a poem by Paul Lawrence [sic] Dunbar called Death Song" ([Varèse] 1925). Evidently Still "finished and then discarded" this work (Arvey 1984, 66). 
forebears of ante-bellum days." Florence Mills had starred previously in at least two shows for which Still played oboe in the pit orchestraShuffle Along (1921) and Dixie to Broadway (1924). Significantly, the latter, like many black revues of the day, was set partly in the South, with its first scene titled "Evolution of the Colored Race" (Sampson 1980, 193). Still adapted this theme for his Levee Land, "elevating" it for the concert stage.

At the same time, aspects of Levee Land's style place it at a distance from the Afro-American Symphony. It was scored for a chamber ensemble of two violins, two clarinets, bass clarinet, alto saxophone, bassoon, horn, trumpet, trombone, banjo, piano, and percussion-a combination not that far from Gershwin's Rhapsody in Blue, as scored by Ferde Grofé for Paul Whiteman's Orchestra. ${ }^{10}$ Still wrote the text himself, with its dialect recalling the style of the black poet Paul Laurence Dunbar and its rhythms suggesting the blues-inspired verse of Langston Hughes. The first stanza, as printed in the Guild program, gives a sense of Still's language throughout:

Oh, baby! Baby, baby, baby

Oh, baby! Ah feels so blue,

Sittin' on de Levee

A longin', babe, fo' you (given in Varèse 1926a).

Levee Land is in four parts, "Levee Song," "Hey-Hey," "Croon," and "The Backslider." The first and fourth parts feature a song text; the second incorporates spoken, comic interjections; and the third uses a wordless vocal, much like Still's earlier work, From the Land of Dreams. Throughout, Still strikes a compromise between an accessible black idiom-in this case the blues, which serves not only as a basis for some of the formal structures but permeates the harmonic language as welland the more esoteric world of modernist concert music. While the piece is a hybrid similar to Gershwin's Rhapsody in Blue, not only in its scoring but also rhythm, form, and certain harmonic gestures, it is distinctively different in other ways, especially its use of dissonance. From the outset the piece functions on two distinct planes. On one level there is the vocalist's melodic line together with supporting instruments, which present conventional blues-derived melodies and harmonies, and on another there are chromatic-third relationships that play off a basic

10. The original scoring of Rhapsody in Blue differed from that of Levee Land in several ways: it used a tenor saxophone, double bass, tuba, and celeste but included no bassoon and had a slightly different battery of percussion. 
Example 1. William Grant Still, "Levee Song" from Levee Land, mm. 1-14
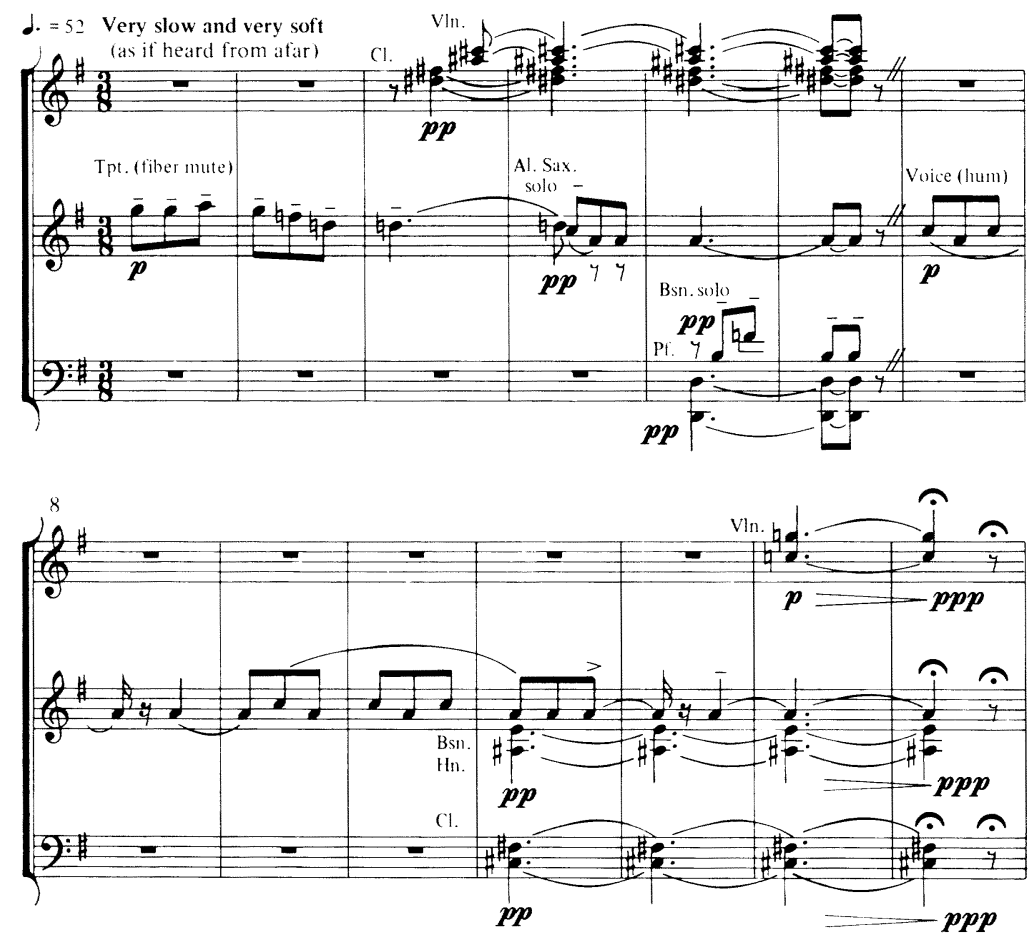

trait of the blues but do so using the techniques of the young modernists. In the introduction, for example, the trumpet, alto saxophone, and bassoon seamlessly lead to a two-note wordless vocal on $a$ and $c$ (see Ex. 1). But their traditional blues inflection is juxtaposed, from the very beginning, with clashing dissonant thirds. The clarinets in the third measure sound $d \sharp$ and $f \sharp$ against $d \notin$ in the trumpet, and the violins then pile on another layer ( $a \#$ and $c \#$ ) a third above the previous one. When the first stanza begins at measure 26 (see Ex. 2), a similar technique appears. The vocalist sings a straightforward blues-derived line that is well supported by a standard blues harmony and vamp-like chords in the piano, violin, and bassoon. Cascading under it on another plane is a string of chromatic thirds in parallel motion. 
Example 2. William Grant Still, "Levee Song" from Levee Land, mm. 26-29
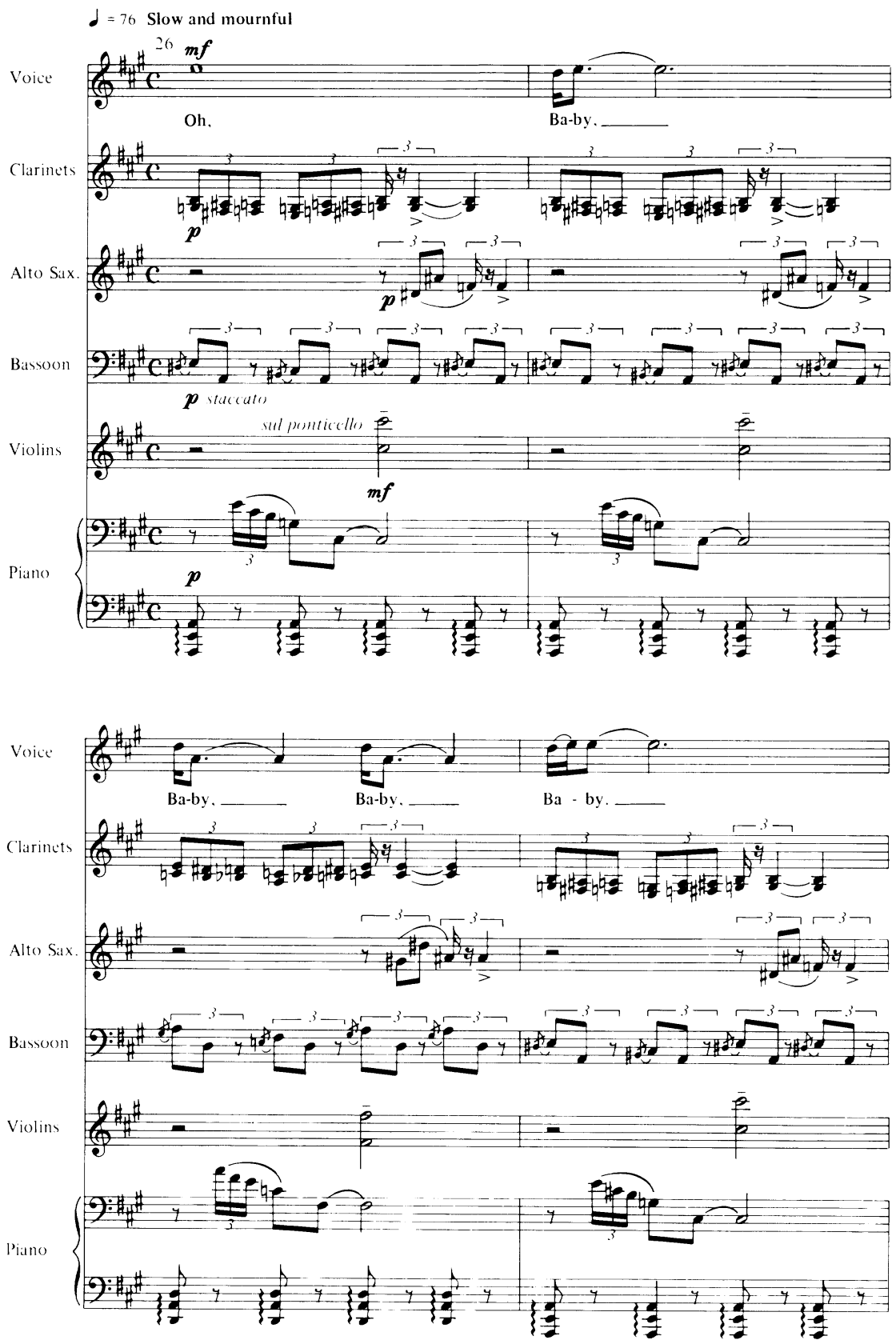
The piece uses this same principle throughout, encircling familiar African-American gestures with modernist chromaticism. By doing this, Still met both a practical necessity and an aesthetic ideal. He taught these songs to Mills by rote and had the responsibility of keeping at least one layer of the ensemble within a sonic world familiar to her (Arvey 1984, 69). At the same time he did not simply transplant the style of the black revue or of jazz orchestras to the concert hall. Instead he sought to transform it.

With Still's last performance by the International Composers' Guild in November 1926, he once again offered a piece that synthesized black idioms with areas of intense chromaticism, and he did so in much the same way as he had in Levee Land: by employing planes-or whole areas - that evoked African-American traditions and juxtaposing them, either vertically or horizontally, with a dissonant fabric. The piece was Darker America, composed in 1924, and it exhibits even stronger links to the Afro-American Symphony. Before enumerating these connections, Still's description of the piece, as printed in the Guild's program, is worth quoting in full:

Darker America, as its title suggests, is representative of the American Negro. His serious side is presented and is intended to suggest the triumph of a people over their sorrows through fervent prayer. At the beginning the theme of the American Negro is announced by the strings in unison. Following a short development of this, the English horn announces the sorrow theme which is followed immediately by the theme of hope, given to muted brass accompanied by strings and woodwind. The sorrow theme returns treated differently, indicative of more intense sorrow as contrasted to passive sorrow indicated at the initial appearance of the theme. Again hope appears and the people seem about to rise above their troubles. But sorrow triumphs. Then the prayer is heard (given to oboe); the prayer of numbed rather than anguished souls. Strongly contrasted moods follow, leading up to the triumph of the people near the end, at which point the three principal themes are combined (quoted in Varèse 1926b).

Still tells much in this short paragraph, and his words foreshadow ideas that are further developed in the Afro-American Symphony. First, the two works share a similar program, not only in depicting the lives of African-Americans but in marking a progression from a lowly state to a nobler one. In Darker America Still does this by employing themes that converge to suggest "the triumph of the people," while in the AfroAmerican Symphony his evolutionary scheme surfaces in the titles of movements, which move from "Longing" to "Aspiration" ("Notes on: 
The Afro-American Symphony" [n.d.]), and in the choice of poems by Dunbar that Still added to the movements after the work was finished. The first three poems appended to the Afro-American Symphony are written in black dialect, invoking African-American common folk, and the fourth, with its words of affirmation, "Be proud, my Race, in mind and soul," uses mainstream American English. Both works also illustrate four concepts or states of mind. In Darker America, these are articulated as themes: (1) American Negro, (2) sorrow, (3) hope, and (4) prayer. In the Afro-American Symphony they appear as four movements: (1) Longing, (2) Sorrow, (3) Humor, and (4) Aspiration. The orchestration of both is also quite similar, the principal difference being that the Afro-American Symphony uses a larger ensemble. ${ }^{11}$

Yet in style Darker America is closer to Levee Land than to the AfroAmerican Symphony. Written only a year apart, while Still continued to be connected to Varèse and the Guild, both combined blues-based African-American writing with modernist chromaticism. In the opening measures of Darker America, for example, unison strings proclaim the mournful theme of the "American Negro," which is unambiguously in G-minor. Immediately, as in Levee Land, Still injects an alien sound world but does so based on the traditional technique of call-andresponse. The music for the "call" imitates black vernacular idioms of uptown New York, and that for the "response" is a dissonant crash from downtown. Note the second beat of measure two (see Ex. 3) where the horns and piano right hand enunciate G-minor, and the lower strings and piano left hand interject a counterthrust of $f, c \sharp$, and $e$. Or, put another way, in the second measure the G-minor of the opening melody combines with a dissonant third ( $c \sharp$ and $e$ ). That third, in turn, has an added augmented fifth below (on $f$ ). This kind of technique continues throughout the work: areas utilizing blues-derived harmonies alternate with ones of intense chromaticism. Most of the former accompany the second theme of "sorrow."

11. The two works employ nearly the same instrumentation, yet where Darker America has two flutes, the symphony has three; where Darker America has one oboe, the symphony has two. Other differences come in the percussion-there is a much more diverse battery in the later piece-and in the use of piano in Darker America (it is absent in the symphony) and banjo in the symphony (it is absent in Darker America). According to the Guild program notes, Still scored two versions of Darker America, one for large orchestra (this is the published score, used in the above comparison) and another for chamber ensemble (this is the one performed by the Guild, which incorporated the same winds, no percussion, and a string quintet) (Varese 1926b). 
Example 3. William Grant Still, Darker America, mm. 1-8
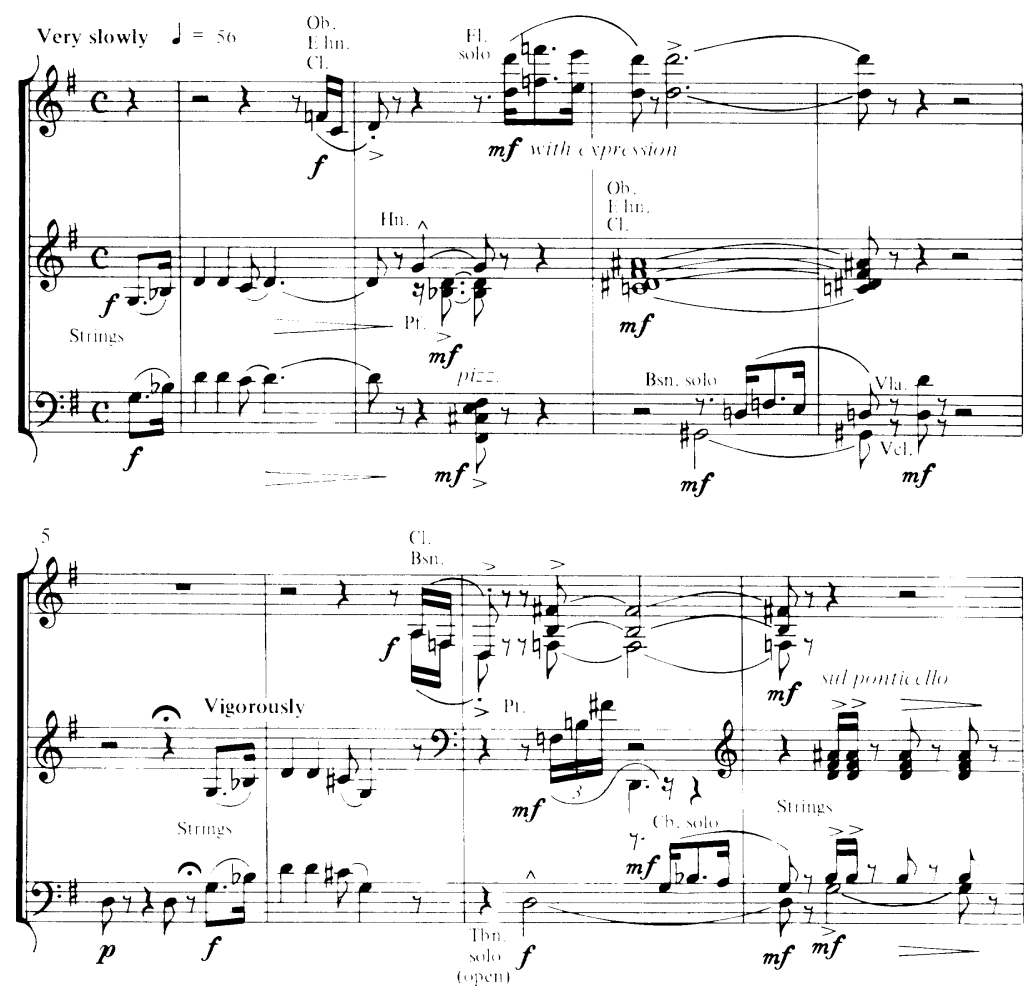

Another striking aspect of Darker America is its form. Just as Still says in his program note, the four musical themes appear, one after another (quoted in Varèse 1926b). Some recur, and secondary themes enter as well. There is a central section of development, where the sorrow theme returns especially frequently, and the themes coalesce at the end for the section of "triumph" described by Still, although it becomes a quiet victory. Hence the work is highly sectional, and those sections are connected by dramatically orchestrated transitions, resembling the potpourri of hit tunes that make up the overture to a musical comedy more than any standard European symphonic form. Downes (1926b), in reviewing the Guild concert, objected to this trait, although he admired the piece as a whole: "What is lacking [in Darker America] is actual de- 
velopment and organic growth of the ideas. This music, however, has direction and feeling in it, qualities usually lacking in contemporaneous music." By bringing the conventional standards of concert music to his criticism, Downes ignored the possibility that this kind of discontinuous formal structure might have grown out of Still's work as an arranger and that such a source could be credible. Instead he saw it as a shortcoming. ${ }^{12}$

Throughout the late 1920s Still managed the same fruitful yet precarious balance between pursuing the ideals of the Harlem Renaissance and participating in the young composers' scene. A summary of his most important remaining New York performances during the decade shows the scope of his activity up to the symphony's premiere (see Appendix). After the performance of Darker America in 1926, which ended Still's association with the Guild (it ceased to exist a year later), his music immediately moved to other new music venues-first the Little Symphony, then the American Composers' Concerts in Rochester. These two organizations placed Still in an environment related to that of the Guild but with some notable differences. Barrère's Little Symphony, which performed three works by Still before the end of the twenties, by no means devoted itself exclusively to new compositions. Lesser-known European classics appeared alongside works by an eclectic group of contemporary figures, some of whom represented strong conservative tendencies. Included among the more tradition-bound American composers on Barrère's roster were Charles Tomlinson Griffes, Mary Howe, and Henry Hadley. John Alden Carpenter, McPhee, and Wallingford Riegger represented a more adventuresome wing, and Arthur Honegger and Heitor Villa-Lobos were among the few foreign names (Little Symphony Programs 1926-1930).

With Hanson's American Composers' Concerts Still gained his most consistently loyal performance outlet. At the same time, this new alliance reflected the deepening conservatism of his style. Hanson programmed at least one piece by Still almost every year from 1927 to 1945, the highpoint being his premiere of the Afro-American Symphony. He also gave Still one of his earliest publishing opportunities when he issued Darker America as part of an Eastman-sponsored series in 1928-a series

12. It should be noted, however, that within a few years Still echoed Downes's judgment of Darker America. Responding to Schwerkés request for a copy of the score, Still wrote: "DARKER AMERICA, being an earlier work, has many faults. Lack of continuity, harmonization not altogether characteristic, insufficient development as well as other defects" (Still 1931b). 
through which pieces were chosen for publication by an audience vote taken after performances ("Audience and Critics Vote" 1927). Since Hanson's personal tastes were far less adventuresome than Varèse's, his concerts had a different profile from those of the Guild. Conservativeand often older-composers such as Ernst Bacon, Charles Wakefield Cadman, and Arthur Foote shared the roster with younger, more independent spirits such as Copland, Cowell, and Harris. The former outweighed the latter, however, and this too said something about Still's turn away from a modernist language. In the Afro-American Symphony, conventional, blues-derived harmonic practices prevail. The piece is more consonant, more accessible, and perhaps more expressive of "what the masses of [the] race were then feeling and thinking and wanting to hear," as James Weldon Johnson $(1930,263)$ defined one of the goals of the Harlem Renaissance. Still himself later acknowledged: "Through experimentation, I discovered that Negro music tends to lose its identity when subjected to the avant-garde style of treatment" (Still [1970] 1975a, 134). Hanson certainly admired the stylistic conservatism that resulted and confirmed this in a tribute to Still written many years later: "William Grant Still brought to [American] music a new voice, a voice filled with lovely melodies, gorgeous harmonies, insidious rhythms, and dazzling colors. But it was a new music deeply rooted in the traditions of the past. ... His music speaks to the common man" (quoted in Southern 1985, 9). Hanson's words, like those of many other writers about Still, missed the complexity of the man's musical personality. He had a daring streak as well as a conservative one.

When added together, these performances by Varèse, Barrère, and Hanson gave Still's music substantial representation in the otherwise white world of American new music. Further sense of Still's standing with the modernists comes from a number of important written assessments made around the time of the Afro-American Symphony's premiere. Still's name consistently was included among the most promising and active composers of his generation, but evaluations of his achievement varied. Perhaps the most important barometers were Cowell's American Composers on American Music and Copland's Modern Music article, "The Composer in America, 1923-1933," both published in 1933.

Cowell placed Still in the select group of twenty-eight contemporary composers given short biographies at the end of the book, and he published an article by Still, titled "An Afro-American Composer's Point of 
View."13 Furthermore, Cowell discussed Still in the introduction, where he charted "Trends in American Music." There Still did not fare as well, although he was by no means alone in being criticized by Cowell. After dividing American composers into groups such as those "who have developed indigenous materials" (Ives, Ruggles, Seeger, Harris, Brant, Crawford, McPhee, and Cowell himself) or those "who are in many respects original but who are influenced by modern Teutonic music" (Adolph Weiss, Wallingford Riegger, John J. Becker, Gerald Strang, and Richard Donovan), Cowell wrote of Still as a composer outside any category:

There are also two interesting individual cases which are difficult to group [T. Carl Whitmer, a long-since forgotten figure, was the other]: William Grant Still, Negro, uses his people's themes and feelings as a base for his music, which is otherwise in modern style with some rather vague European influence. Perhaps he possesses the beginnings of a genuine new style. At present, however, his works are unformed and contain many crudities. Only later developments will show whether or not his present promise will be fulfilled (Cowell [1933] 1961, 11).

Copland's article, by contrast, had more positive implications for Still, including him in a list of sixteen figures who represented "an entirely new generation of composers. . . . These men form, for better or worse, the American school of composers of our own day" (Copland 1933, 90). Other prominent names on his list were Antheil, Cowell, Harris, Sessions, and Thomson. Since Copland's purpose was not to evaluate his contemporaries but to chronicle developments in American composition since World War I, he offered no detailed profiles.

Still's name also appeared in two other important publications from around 1930: Claire Reis's American Composers of Today (1930) and Paul Rosenfeld's An Hour with American Music (1929). Reis, who was founding director of the League of Composers and a board member of the United States Section of the International Society for Contemporary Music, published a catalog of rifty-five composers who "sum up America's

13. The twenty-eight composers chosen by Cowell represented mostly figures he championed but also others to whom he was not as sympathetic: George Antheil, John J. Becker, Henry Brant, Alejandro Garcia Caturla, Theodore Chanler, Chàvez, Copland, Cowell, Ruth Crawford, Gershwin, Hanson, Harris, Ives, McPhee, Walter Piston, Riegger, Amadeo Roldan, Edward Royce, Dane Rudhyar, Ruggles, Carlos Salzedo, Lazare Saminsky, Charles Seeger, Sessions, Nicolas Slonimsky, Varèse, and Adolph Weiss. Still's essay stood among others by Rudhyar ("Oriental Influence in American Music"), Gershwin ("The Relation of Jazz to American Music"), and Ives ("Music and Its Future"). 
creative contribution to contemporary music" (Reis 1930, [i]). It was a unique information guide, giving performers, conductors, and publishers a sense of the available music. Still thanked Reis after both the first and second editions of her catalog, affirming in 1932 that inclusion in such a volume bolstered his spirits: "The recognition you give me therein means so much. It tells me this ... America is interested in my efforts" (Still 1932).

While Reis's book imparted basic information, Rosenfeld's An Hour with American Music gave a highly opinionated view of contemporary American composition as seen by its shrewdest and most sympathetic critic. Rosenfeld promoted this generation of composers vigorously. $\mathrm{He}$ had been an admirer of Still's From the Land of Dreams, but as the years passed Rosenfeld grew less supportive, perhaps because Still's work increasingly incorporated vernacular idioms. ${ }^{14}$ Despite his open-mindedness about American concert music, Rosenfeld was a confirmed upholder of high culture who held distinct biases-mostly class-related ones. In other words, he supported the new American music that fit into the most elevated European concert traditions, even if its language was ever so experimental, and he had little sympathy for vernacular styles, whatever their racial or ethnic source. By the time of An Hour with American Music in 1929, Rosenfeld dismissed Still briefly by placing him next to Gershwin, whom Rosenfeld declared as "assuredly a gifted composer of the lower, unpretentious order" (Rosenfeld 1929, 138). He also found that Still's work fell short of Copland's, which represented for Rosenfeld the "most advanced sort of product ... in American music":

The experiments of William Grant Still with jazz and the blues compare favorably with those of Gershwin; but the difference between his jazz music and Copland's is still huge. For Copland has actually absorbed jazz motives and correlated them with the developments of the past (Rosenfeld $1929,127,139$ ).

There were other arenas of American musical modernism from which Still was conspicuously absent. Most noticeable were the concerts and

14. Rosenfeld seems to have sustained his support of Still at least through 1927. His favorable review of From the Land of Dreams in 1925 has been discussed above, as has his focus on Florence Mills in covering Levee Land. He appears not to have reviewed Still's Darker America. Yet in 1927 Rosenfeld continued to endorse Still. That spring he arranged a concert at the New School for Social Research in New York that included Still's "Dialect Songs" (one of which was "Winter's Approach," set to a text by Dunbar) together with music of Copland, Sessions, Chanler, and others. The composers were called by Marianne Moore ([1927] 1986, 187), writing in The Dial, "Mr. Rosenfeld's little family of geniuses." 
publications of the League of Composers and its offshoots, where Still's name seldom surfaced. During the 1920 s and into the 1930 s no work of Still's appeared on a program of the League. This was not surprising for a variety of reasons. In its early years the League focused on European modernists and performed few homegrown products, with the exception of an annual "Recital of New Music by Young Americans" initiated in the fall of 1924 and continuing regularly after 1926. However, its pool of composers for that series differed markedly from the Guild. ${ }^{15}$ Similarly, Modern Music, the journal of the League that was the principal source for information about America's new music, published no profile of Still. ${ }^{16}$ The Copland-Sessions Concerts, which were an informal and youthful extension of the League, did not include his music, and Cos Cob Press, the music publishing enterprise that served as another informal appendage of the League, did not issue his scores. In 1936, after the Afro-American Symphony, Still had his only breakthrough with the League: a commission for an orchestral work. Still submitted two scores, Dismal Swamp and Kaintuck', asking that the League's board choose the one they wanted (Still 1935). The League selected Kaintuck' but apparently never performed it. Dismal Swamp was published the next year in Henry Cowell's New Music Orchestra Series-the first score by Still that Cowell issued.

On the whole, however, the modernists included Still much more often than they excluded him, providing the performance outlets essential for his growth as a composer-a function that they served for a whole generation of young Americans. Yet despite the parallels between Still and figures such as Copland and Cowell, he remained a figure set apart. No other composer, either black or white, claimed quite the same turf. As a "New Negro" seeking to express himself through the "New Music," he led a slightly schizoid existence, and the Afro-American Symphony, together with the series of works that led up to it, reflected that duality. While retaining its landmark status in African-American music, the symphony also belongs to the history of the very organizations that made its conception and first performance possible. Perhaps an inte-

15. Thomson, for example, did not have a work programmed by the League until 1933 (although Thomson, unlike Still, played no role in the Guild), and McPhee, Varèse's other main pupil during the twenties, had no music on League concerts during the twenties.

16. Modern Music began a series of profiles of American composers in 1928, and Ruth Crawford Seeger was also omitted from it. Still was not completely ignored in the magazine, however; his music was mentioned in a series of articles and reviews connected with Hanson's concerts in Rochester (Rogers 1931, 40-41; Balaban 1932, 182-183; Hanson 1943, $100-101)$. 
grated approach to the writing of America's music history-an approach largely lacking at present-will lead to a more balanced understanding of works such as this. The Afro-American Symphony may have appeared in a country with strong strictures for segregation, but informally and ideologically those walls were in the process of breaking down.

\section{MUSIC LIST}

Still, William Grant. n.d. Levee Land. [Flagstaff, Ariz.]: William Grant Still Music. (Composed in 1925)

- 1928. Darker America. Boston: E. C. Birchard for the Eastman School. (Composed in 1924)

1935. Afro-American Symphony. New York: J. Fischer \& Bro. (Composed in 1930)

1937. Kaintuck'. [Flagstaff, Ariz.]: William Grant Still Music.

1937. Dismal Swamp. New Music Orchestra Series, no. 21. San Francisco: The New Music Society of California.

\section{REFERENCES}

Allen, Walter C. 1973. Hendersonia: The music of Fletcher Henderson and his musicians. Highland Park, N.J.: Walter C. Allen.

Arvey, Verna. 1975. Memo for musicologists. In William Grant Still and the fusion of cultures in American music, edited by R. B. Haas, 88-93. Los Angeles: Black Sparrow Press.

- 1984. In one lifetime. With an introduction by B. A. Nugent. Fayetteville: University of Arkansas Press.

Audience and critics vote on compositions. 1927. New York Times November 22:32.

Balaban, Emanuel. 1932. Progress at Rochester. Modern Music 9:182-184.

Brown, Rae Linda. 1990. William Grant Still, Florence Price, and William Dawson: Echoes of the Harlem Renaissance. In Black music in the Harlem Renaissance: A collection of essays, edited by Samuel A. Floyd, Jr., 71-86. New York: Greenwood Press.

Contest for composers. 1930. Musical Leader 58 (January 9):6.

Copland, Aaron. 1933. The composer in America, 1923-1933. Modern Music 10, no. 2 (January-February):87-92.

Cowell, Henry, ed. [1933] 1961. American composers on American music: A symposium. New York: Frederick Ungar.

Cowley, Malcolm. [1934] 1951. Exiles retum: A literary odyssey of the 1920s. New York: Viking Press.

Downes, Olin. 1925. Music. New York Times February 9:15.

- 1926a. Music. New York Times February 25:25. 1926b. Music. New York Times November 29:16.

Haas, Robert Bartlett, ed. 1975. William Grant Still and the fusion of cultures in American music. Los Angeles: Black Sparrow Press. 
Hanson, Howard. 1943. Twenty years' growth in America. Modern Music 20:95-101.

Huggins, Nathan Irvin. 1971. Harlem Renaissance. New York: Oxford University Press.

Johnson, James Weldon. 1930. Black Manhattan. New York: Alfred A. Knopf.

Lederman, Minna. 1983. The life and death of a small magazine (Modern Music, 1924-46). Brooklyn, N.Y.: Institute for Studies in American Music.

Little Symphony programs. 1926-1930. Season surveys (1926-1927 and 1929-1930) and programs (March 18, 1928, March 23, 1930, March 30, 1930, April 6, 1930, June 11 [no year], June 18 [no year]). Music Division, New York Public Library, New York City.

Locke, Alain. 1936. The Negro and his music. Washington, D.C.: Associates in Negro Folk Education.

Lott, R. Allen. 1983. "New music for new ears": The International Composers' Guild. Journal of the American Musicological Society 36:266-286.

May, Henry. 1959. The end of American innocence: A study of the first years of our own time, 1912-1917. New York: Alfred A. Knopf.

Mead, Rita. 1981. Henry Cowell's New Music, 1925-1936: The society, the music editions, and the recordings. Ann Arbor, Mich.: UMI Research Press.

Moore, Marianne. [1927] 1986. Comment, for The Dial. In The complete prose of Marianne Moore, edited by Patricia C. Willis, 186-187. New York: Viking.

Notes on: The Afro-American Symphony. n.d. Typescript. Collection of Judith Anne Still, Flagstaff, Arizona.

Oja, Carol J. 1979. The Copland-Sessions Concerts and their reception in the contemporary press. Musical Quarterly 65:212-229.

- 1988. Cos Cob Press and the American composer. [Music Library Association] Notes 45:227-252.

Reis, Claire R. 1930. American composers of today. 1st ed. New York: International Society for Contemporary Music, U.S. Section.

- [1955] 1974. Composers, conductors, and critics. New York: Da Capo Press.

Rogers, Bernard. 1931. Rochester's American series. Modern Music 8:39-42.

Root, Deane L. 1972. The Pan American Association of Composers (1928-1934). Yearbook for Inter-American Musical Research 8:49-70.

Rosenfeld, Paul. 1925. Musical chronicle. The Dial 78:349-353.

-1926. Musical chronicle. The Dial 80:349-352.

1929. An hour with American music. Philadelphia: J. B. Lippincott.

Ruggles, Carl. 1926. Letter to Blanche Walton, November 19. Walton Collection. Music Division, New York Public Library, New York City.

Sampson, Henry T. 1980. Blacks in blackface: A source book on early black musical shows. Metuchen, N.J.: Scarecrow Press.

Southern, Eileen. 1983. The music of black Americans: A history. 2nd ed. New York: W. W. Norton.

- 1985. William Grant Still-trailblazer. In William Grant Still studies at the University of Arkansas: A 1984 congress report, edited by Claire Detels. Fayetteville: University of Arkansas Fulbright College of Arts and Sciences.

Still, William Grant. 1931a. Letter to Irving Schwerké, January 9. Schwerké Collection. Music Division, Library of Congress, Washington, D.C.

- 1931b. Letter to Irving Schwerké, February 27. Schwerké Collection. Music Division, Library of Congress, Washington, D.C.

- 1931c. Notes for the Afro-American Symphony. Typescript, October. Schwerké Collection. Music Division, Library of Congress, Washington, D.C.

- 1932. Letter to Claire Reis, December 30. Reis Collection. Music Division, New York Public Library, New York City. 
1935. Letter to Claire Reis, May 11. Reis Collection. Music Division, New York Public Library, New York City.

- [1970] 1975a. A composer's viewpoint. In William Grant Still and the fusion of cultures in American music, edited by R. B. Haas, 124-139. New York: Black Sparrow Press.

- 1975b. Horizons unlimited. In William Grant Still and the fusion of cultures in American music, edited by R. B. Haas, 113-123. New York: Black Sparrow Press.

[Varèse, Louise]. 1925. Program notes, International Composers' Guild Concert, February 8. ICG Programs. Music Division, New York Public Library, New York City.

Varèse, Louise. 1926a. Program notes, International Composers' Guild Concert, January 24. ICG Programs. Music Division, New York Public Library, New York City.

— 1926b. Program notes, International Composers' Guild Concert, November 28. ICG Programs. Music Division, New York Public Library, New York City.

- 1972. Varèse, a looking glass diary, vol. 1: 1883-1928. New York: W. W. Norton.

Watanabe, Ruth. 1972. The Institute of American Music of the University of Rochester: American Composers' Concerts and Festioals of American Music, 1925-1971. Rochester, N.Y.: Eastman School of Music.

Wiecki, Ronald V. 1992. A chronicle of Pro Musica in the United States (1920-1944): With a biographical sketch of its founder, E. Robert Schmitz. Ph.D. diss., University of Wisconsin-Madison.

\section{APPENDIX}

\section{WORKS OF WiLliam GRANT STILL PERFORMED BY NeW Music ORGANIZATIONS, 1926-1931}

\section{International Composers' Guild (New York City)}

From the Land of Dreams, February 8, 1925

Levee Land (text by William Grant Still), January 24, 1926, with

Florence Mills as soloist

Darker America, November 28, 1926

The Little Symphony Orchestra, conducted by Georges Barrère (New York City)

From the Black Belt, March 20, 1927

Log Cabin Ballads, March 18, 1928

Africa, April 6, 1930

American Composers' Concerts, conducted by Howard Hanson

(Rochester, New York)

Darker America, 1927-1928 season, and 1929-1930 season

From the Journal of a Wanderer, 1928-1929 season

Sahdji (ballet), 1930-1931 season

Africa, 1930-1931 season

Afro-American Symphony, 1931-1932 season 